\title{
Private school investments and inequalities: negotiating the future in transnational Dakar
}

\author{
Amélie Grysole
}

In Dakar in 2013, I asked Pierrot Gueye ${ }^{1}$ where his son went to elementary school. When Pierrot explained that he attended a private school, I commented that 'Notre Dame Elisabeth is a very good school!', presuming he referred to the well-known private school in his neighbourhood. Pierrot looked surprised and responded: 'No, no, no. He goes to the one on the other side of the street, Al Kitaba.' It had not occurred to me that Pierrot Gueye, who was himself educated to university level in French schools in Dakar, would choose to send his son to a school where classes were taught in Arabic as well as French, rather than the wellreputed French-language school nearby. Furthermore, Pierrot's nieces and nephews who lived on the ground floor of the Gueye house all attended private French schools, funded by remittances from abroad. In Senegal, children who live together commonly attend different schools, indexing adults' unequal investments in their futures. In neoliberal Dakar, resources from international migration have widened inequalities within and between families.

Francophone diplomas (such as those students earn at Notre Dame Elisabeth) provide access to salaried employment in Senegal and are commonly recognized abroad, whereas the value of diplomas from Franco-Arabic schools on the formal labour market remains uncertain, given that these institutions gained official state recognition only recently. Yet, teaching in Arabic has a long history and cultural legitimacy in Senegal and might provide access to informal economic and religious networks. Whether a child goes to school on one side of the street or the other can thus index the future paths parents imagine possible for their children, in Senegal and abroad. ${ }^{2}$

In this article, I analyse the recent proliferation of private schools in Dakar and the ways in which Senegalese parents navigate the multiplicity of school choices, in order to understand how families struggle to ensure their social and material reproduction in a neoliberal economy. I suggest that educational choices are situated at the intersection of global and intra-family inequalities. The unequal distribution of resources among family members reflects long-standing patterns of asymmetrical and complementary relationships among kin organized by gender

\footnotetext{
Amélie Grysole is a PhD student in sociology at the Centre Maurice Halbwachs (École des Hautes Études en Sciences Sociales and École Normale Supérieure) and at the Institut National d'Études Démographiques. Her research interests include migration, gender and domestic economy, social status and transnational reproduction, and the value of children and schooling investments. Email: agrysole@yahoo.fr

${ }^{1}$ All names are pseudonyms to protect research participants' privacy.

${ }^{2}$ This article is based on ethnographic fieldwork conducted between 2013 and 2015 in Yoff (Dakar), the US (New York State and Rhode Island) and Italy (Milan and Genoa). I focused specifically on transnational families in which migrants' children have been sent back to maternal aunts or grandmothers in Dakar (on children sent back to Africa, see Kane 2011; Bledsoe and Sow 2011; Grysole and Beauchemin 2013; Coe 2014; Kea 2016).
} 
and generation (Buggenhagen 2012; Moya 2017). In recent years, international migration has made global inequalities apparent within and between Senegalese families, who are unequally positioned depending on whether they include members living abroad.

Successive neoliberal reforms since the 1980s have dramatically reduced funding for state services and the number of public sector jobs in Senegal (Ridell 1992; Osmont 1995). Austerity measures associated with programmes of structural adjustment reconfigured the value of a francophone education, once thought to provide sure access to salaried employment, and encouraged an influx of international migration (Adepoju 2000). Increasing rates of unemployment in Dakar and tightening immigration controls in France have led Senegalese to migrate to new destinations, including the US, Italy and Spain (Lessault and Flahaux 2013; Fall 2016).

In this context of economic volatility, family life in Senegal is characterized by anxiety and uncertainty about the future. An examination of schooling choices in Senegalese families sheds light on parents' efforts to invest in their children's, and thus their own, futures. Whether to fund a child's private schooling and at which institution is a choice shaped by adults' desires to demonstrate their own success, to invest in promising children, to redistribute resources within the family, and to secure the material future of their kin group. Investments in children's education exist in a logic of intergenerational reciprocity: adults hope that, later on, successful children will be able and willing to provide for their benefactors. The prestige and potential future security provided by astute investments in the right child and the right school are more readily available to migrants, who often devote large portions of their earnings abroad to school fees for their own and their relatives' children. Non-migrants often struggle to offer their children similar opportunities.

Some authors on kinship and migration have criticized the view of migration as an exceptional situation that creates problems and suffering for families, who are tacitly presumed to be co-residing nuclear units (Bryceson and Vuorela 2002; Razy and Baby-Collin 2011; Baldassar and Merla 2013). Africanist scholars have demonstrated that the 'materiality of care' (Coe 2011) is arguably as important to the maintenance of kinship relations as are spatial proximity and daily care (see also Cole and Groes 2016). In this article, I use school investments to track who finances and cares for which child, locally or transnationally.

Focusing on the children in a single household in Dakar, this article examines school choices made by adults in Senegal and abroad, to highlight the ways in which global inequalities are reflected in unequal investments in children's education. In my fieldwork, the children of migrants were, without exception, enrolled in private schools, whereas other children in their households often attended public schools. In the Gueye home, the children of migrants and non-migrants alike all went to private schools, but the type of school, language of instruction, cost of fees and location varied for each child.

The Gueye house was a large, two-storey family home in Yoff, a suburb of Dakar, that Pierrot's father had built in the 1970s. The first floor was occupied by Pierrot (who had never migrated), his wife and children. Pierrot's half-siblings (of a different mother) and their children occupied the ground floor, where several migrants contributed to the budget, including Khady Gueye, who lived in the US. Through the analysis of the Gueye home, I propose to deliver a living portrait of a 
modern family and the strategies of social ascension over three generations. To deal with everyday issues such as educating the next generation, adults make strategic choices depending on their current socio-economic position and future horizons with respect to long-standing 'economic moralities' in Senegal (Maurer 2009; Yount-André 2017).

I first present the diversification of the educational landscape in Dakar over the last twenty years. The multiplicity of private school types and the diverse opportunities to which each type could provide access have made investing in schooling a complicated gamble for parents. I then develop the analytical concept of maisonnée (Weber 2002), which represents an intimate and economic unit that may include people beyond those who co-habit (such as migrants) and might exclude kin who live together in one physical house but do not share everyday expenses. Here, I use the maisonnée to delineate kin who pool their resources for child-rearing and group social mobility. I argue that the Gueye 'family home' (këru famiy) or paternal house (kër baay) physically anchors two maisonnées, one downstairs (which includes Khady and another migrant) and one upstairs (Pierrot's, which includes no migrants). Through an examination of the school choices of Khady's downstairs maisonnée, I demonstrate how unequal relationships between adults (relative to gender, age, social achievement and education) and the potential of each child (including opportunities to migrate) lead to divergent school choices and uneven investments in children from the same maisonnée. Finally, an analysis of Pierrot's upstairs maisonnée demonstrates how investments in local legitimacy may provide a means of coping with economic decline, as experienced by many in Senegal who have not succeeded in migrating.

\section{The gamble of children's schooling under neoliberal capitalism}

My fieldwork took place in a crowded suburb of Dakar called Yoff, in the homes of geer (non-casted) and Lebu families with member(s) who had migrated abroad. These large households represent heterogeneous family units living in common properties, and often include inhabitants from several socio-economic levels. These families belong to the lower middle class in Dakar, characterized by high schooling aspirations for children, but with a deep anxiety about families' social and material reproduction (see Darbon 2012; Noret 2016). In this section, I examine how Muslim parents navigate between private school choices with different regimes of value and opportunity. Given historical political-economic changes and transformations in Senegal's educational system, French education and ArabicIslamic knowledge can both lead to opportunities and a child's success in life.

Pierrot and Khady's father, Ousmane Gueye, built his family's two-storey house in Yoff at a time when most houses in the neighbourhood had one single floor and simple sheet-metal roofs. Deceased in 2006, Ousmane had a successful trajectory without francophone education. Having attended a Qur'anic school (daara) in Rufisque, he worked as a bricklayer during a time of rapid urbanization in Dakar, which allowed him to start his own company and hire several workers. He went on to marry four wives and he had nineteen children, securing three key symbols of social success: house, wives and children. 
After Senegal's independence in 1960, Ousmane's neighbours who attended French schools obtained desk jobs as civil servants. French schooling seemed to offer the best opportunities for the future and Ousmane had the means to send Khady, Pierrot and all their siblings to public French schools, some up to university level (see Figure 1). Subsequently, the adult siblings invested significant sums in private schools (French or Franco-Arabic) for the next generation, Ousmane's grandchildren. If, for Ousmane's generation, the key to upward mobility seemed to be investing in formal, francophone public education, today urban parents invest massively in private schooling.

Today, public education is regularly criticized in Senegalese newspapers and everyday conversations. Since the late 1980s, major cutbacks in government spending on education have led to regular teacher strikes and a double-shift system in many public elementary schools, in which one set of students attends school in the morning and another goes in the afternoon. In response, private schools have boomed since the early 2000s. In Dakar, roughly 40 per cent of elementary-level pupils attended private schools in 2013 (République du Sénégal 2015: 28). Whether parents can afford to pay private school tuition fees has become a glaring indicator of socio-economic gaps between and within urban families. ${ }^{3}$ As a result of this privatization, especially of primary schools, parents are faced with an incredibly diverse educational landscape.

At present, there are three main types of private elementary school in Senegal: Catholic, secular, and Franco-Arabic. ${ }^{4}$ The first two types of school are commonly referred to as 'French schools', in that instruction takes place only in French. In Franco-Arabic schools, teaching is in both French and Arabic. ${ }^{5}$ Catholic schools are the oldest private schools in the country and have long been considered the best French schools by Senegalese people. Secular French schools, which were founded from the late 1990s, introduced a wider variety of educational options and levels of performance (Lewandowski 2011). Franco-Arabic schools represent a more recent addition to the 'formal' education system, but Arabic-language schooling has a long history in Senegal.

Qur'anic schools were first established in Senegal in the eleventh century and were a locus of African resistance against colonialization (Ware 2009). When French colonists established a formal francophone education system in the early twentieth century, religious schooling in Arabic did not cease to exist but continued in parallel. To control Qur'anic schooling and encourage Senegalese people to enrol their children in colonial schools, the French authorities established the first Franco-Arabic schools (medersas), where teaching took place in both French and Arabic (Villalón and Bodian 2012). The secular postcolonial state maintained colonial efforts to regulate Qur'anic and Arabic education (Dia 2015). Beginning in the 1970s, modern Islamic associations and later Sufi brotherhoods ran Franco-Arabic schools, with both religious and secular

\footnotetext{
${ }^{3}$ Monthly fees for elementary private schools in Dakar vary from 3,500 (€5) to 25,000 FCFA (€38) (Niang 2014), not including registration, transportation and lunch fees, which can double or triple overall costs.

${ }^{4}$ I do not claim to give an exhaustive list of the types of private school that exist in Senegal. I focus on the area of Dakar and types of school visited during my fieldwork.

${ }^{5}$ It should be noted that the native language of children in Dakar is primarily Wolof.
} 


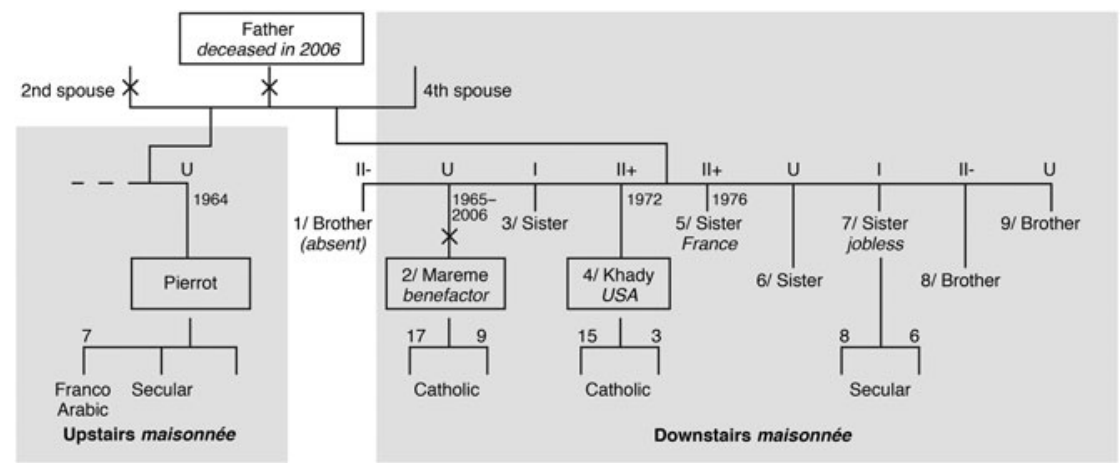

FIGURE 1 School choices for children in upstairs and downstairs maisonnées in $2014 .^{6}$

instruction, in an effort to better prepare Muslim pupils for professional integration. ${ }^{7}$ In 2002, the Senegalese government under Abdoulaye Wade passed a law that allowed private Franco-Arabic schools to award national diplomas and receive state subsides. ${ }^{8}$ In so doing, the government incorporated 'informal' types of Franco-Arabic schooling into the 'formal' education system. This in turn allowed Senegal to reach the imperative of 'universal school attendance' required by international bodies (Lewandowski 2011; D'Aoust 2013; Niang 2014). This ultimately led the state to establish the first high-school examinations in Arabic in 2013. Given the recentness of this shift, Arabic diplomas still have little value in Senegal's contractual labour market.

Charlier (2004) summarizes the hierarchy of private schools as follows: ${ }^{9}$ Catholic schools are highly selective (with high fees and entrance exams) and provide what is perceived to be an elite education. Secular schools accept lower-achieving pupils whose families are able to pay private school fees. Franco-Arabic schools are halfway between the French system and the Qur'anic system. It is noteworthy that Qur'anic education is a priority for Muslim families of all social backgrounds, but usually operates alongside French education. ${ }^{10}$ Finally, Franco-English and

\footnotetext{
${ }^{6}$ The schooling levels of adult siblings are represented by the following: $\mathrm{U}=$ university; $\mathrm{II}+=$ secondary with baccalauréat degree; II- = secondary without baccalauréat; I = elementary. Crosses represent the deceased and numbers the cousins' ages.

${ }^{7}$ Some of those schools were founded by Arab countries (see Lewandowski and Niane 2013: 516-17; Villalón and Bodian 2012).

${ }^{8}$ This law also included the creation of public Franco-Arabic schools and optional religious teaching in all public schools.

${ }^{9}$ In 2013 , roughly 73 per cent of private elementary schools in Dakar were secular, 19 per cent Franco-Arabic, and 4 per cent Catholic (République du Sénégal 2013: 31).

${ }^{10}$ In urban areas, Qur'anic education occurs in early years (from age three to six), then at weekends and during holidays, or with a home Qur'anic teacher. Full-time Qur'anic schools or internships mainly enrol children from rural and/or poorer families. For an overview of the variety of Arabic and Islamic educational options in Senegal, see Lewandowski and Niane (2013) and Dia et al. (2016).
} 
Franco-Italian 'bilingual' schools are the most recent secular school additions to Dakar's diverse educational landscape (see also Hoechner forthcoming for a discussion of English-Arabic schools). These schools were established in response to the schooling needs of migrants and, in some cases, were set up by return migrants themselves.

In the context of this diversification of school types, investing in children's schooling represents a critical gamble for parents. Different types of private schools open up different opportunities for professional integration in the future. Schooling types are also associated with different dimensions of Senegalese cultural identities (French and Western versus Arab, Muslim and local) and skills that may be necessary in the child's upbringing. A 'good' education may be measured in diplomas, religious knowledge, or children's appropriate behaviour. Parents' horizons of expectation - linked to an uneven and changing landscape of opportunities (global and local) - represent a key factor in choosing children's schools. Thinking about which school will provide the best opportunities for economic and social advancement is a tricky calculation bound by parents' means and children's potential. The following section examines the maisonnée as a daily kinship unit whose members pool resources for children's education.

\section{'Bringing children somewhere'}

Pierrot and Khady Gueye grew up in the house their father, Ousmane, built in Yoff. Pierrot lost his mother (Ousmane's second wife) when he was young and Khady's mother (Ousmane's fourth wife) raised him and his siblings. When their father died in 2006, he was retired and his children had already taken over the household expenses. At that time, all inhabitants of the paternal house ate together and Pierrot contributed to the common grocery budget. In 2011, Khady's eldest brother left the Gueye house to live on his own with his two wives and children. Pierrot told me that, at that point, Khady's mother 'freed' him (Pierrot), allowing him to eat upstairs with his wife and children so that he could spend less on the shared household expenses. He was grateful to his stepmother, because he was earning a meagre wage. At that moment, the physical house began to function as two separate economic units, or, in Florence Weber's terms, two separate maisonnées.

Weber $(2002 ; 2005)$ defines a 'maisonnée' as an intimate and economic unit based on practical measures of relatedness whose members do not necessarily live together. This concept is heuristically useful in understanding economic flows within transnational households by treating transnational families as part of multisite maisonnées. A maisonnée represents a changing unit, at a specific moment in time, in which members combine resources (time, money, material goods, skills) for a 'common cause' (Gollac 2003). Members of each maisonnée work together in order to 'bring children somewhere', as expressed by several informants - hopefully to a better socio-economic position than that of the previous generation. Here, I focus specifically on the maisonnée as made up of individuals who work together to provide for children's schooling.

Guyer and Peters have demonstrated that the concept of 'household' as used in demographic and economic surveys is inappropriate for the analysis of African 
domestic economies (Guyer 1981; Guyer and Peters 1987; see also Moya 2017 : 75-7). The resources and residents of a house are 'not organized according to a calculation of total inputs and outgoings, nor with respect to a house as an enclosed unit' (Motta 2014: 124), but rather as intertwined relations, which transcend the walls of a single house and also vary over time. The idea of a household as a closed unit with a shared budget hardly maps on to the daily economic organization of Senegalese kin groups. Rather, different expenses and objectives may delimit separate groups (raising children, eating together, paying school fees or bills, taking care of the elderly, furnishing the house). Houses 'represent knots of financial flows both partitioned and divergent' (Moya 2017: 76) in which each individual draws on personal networks. In this kind of cross-linked economy, the limits of economic units are difficult to determine.

In Wolof, the verb 'to succeed' may be glossed as 'tekki', which means literally 'to untie'. One who has succeeded is unleashed from those on whom he depended. This does not mean, however, that the person is independent or autonomous. Rather, the relationship of dependence is reversed. Being able to care for others represents a crucial part of what characterizes full adult personhood throughout Africa (Cole 2010; 2014; Buggenhagen 2012). The distribution of resources within a maisonnée is organized according to individuals' unequal status positions. Each person has specific rights and obligations, relative to gender, age, school level and work situation. In Senegal, Islamic norms require husbands and fathers to support dependants in their families and beyond, and to provide for their children's education (Moya 2017: 60-1). When fathers reach retirement age, their eldest children (especially boys) who benefited most from the fathers' period of activity should ideally take over providing for their juniors. With rising unemployment in Dakar, this expectation is increasingly difficult for young men to achieve. Today, men often struggle to fulfil the role of sole providers and women commonly contribute to maisonnée budgets.

Economic relations between men and women are a delicate topic in Senegal. According to the value of sutura (discretion), financial arrangements between husband and wife/wives are said to be best left unspoken (Moya 2017: 65). A number of researchers have noted stereotypical remarks both women and men make minimizing women's contribution to household budgets (which can be considerable, especially when women live abroad) and maintaining the myth that the husband, father or eldest brothers manage all household expenses (Adjamagbo et al. 2004; Buggenhagen 2012; Moya 2017: 61-6).

During her first years in the US, Khady regularly sent new shoes and backpacks to Pierrot's children. She explained that she did not want them to 'feel wronged or frustrated' relative to their cousins downstairs, because 'they all are children of the same house'. Pierrot, however, failed to express gratitude, uncomfortable with the gifts his successful younger sibling offered. In the Gueye home, economic inequalities between the downstairs and upstairs maisonnées have widened, in part driven by remittances Khady sends from the US. A subtle social competition has gradually exacerbated this division, notably expressed in comments regarding how each group raises their children. The temporality of 'practical kinship' groups (Bourdieu 1972) is made up of shifting fusions and fissions, alliances and conflicts. The concept of maisonnée, focused on who combines their resources at a given moment, allows us to analyse these reconfigurations over time. 
In my fieldwork among migrants' children and maternal kin in Senegal, I met families in which migrant women contributed significantly to household budgets. This financial participation could, in some cases, call into question their brothers' authority. While the younger brothers of migrant women often suggested that they had a 'right' to be looked after by their older sisters until they could take over care of the maisonnée, Pierrot's example shows that older brothers struggle to accept similar investments. The next section illustrates the ways in which people from the same maisonnée might work together, sharing love, money and care, but not in an undifferentiated manner. In what follows, I examine intra-maisonnée inequalities through an analysis of the downstairs children's schools. I then show how global inequalities are made visible through gambles on schooling choices for Pierrot's children upstairs.

\section{Uneven resource distribution}

I first met the Gueye family in Yoff in January 2013 and I lived with them at various points during my fieldwork. I later met Khady Gueye in the US in 2014. A forty-two-year-old nurse's assistant, Khady had been living in the US since 2009 when she joined her husband, a forty-eight-year-old delivery driver, who had been there since 2003. Khady's two children live in the Gueye home in Yoff, part of the downstairs maisonnée.

Educational investments in a maisonnée's children shed light on the ways in which the redistribution of resources to children is organized by relationships between adult siblings. As Caroline Bledsoe points out: '[T]he way an adult takes care of another's child is more often indicative of the relationship between adults than of the affective link with the child' (1995: 131). Studies on transnational families focus largely on relationships between migrants and their children or ageing parents in their home countries. Here, I focus instead on adult sibling relations, which Thelen and her colleagues suggest provide 'insights into the making and breaking of kinship ties across the life course' in that they are 'as important to the maintenance of families and households as parenthood and marriage' (2013: 2). Siblings' unequal positions - of gender and generation and as migrants or non-migrants - are passed on to the next generation, shaping the circulation of resources.

The school a child attends highlights their parents' status in the kin group. Which adult pays a child's school fees reflects individuals' past relationships as well as the maisonnée's members' beliefs about responsibility and resource distribution. Questions of who makes it possible for a child to attend a costly school often came up spontaneously in conversation as speakers proudly identified a child's benefactor. These public references constitute 'nice words' (wax bu neex or wax bu rafet), which are expected and appreciated in Senegal when someone has been 'generous' (baax in Wolof). The 'bond of education' represents in Senegal 'material-emotional family connections that enabled schooling and resulted from schooling' (Hunter 2014: 467); paying for a child's education therefore 'creates profound obligations that cut across and help to form kinship relations' (ibid.: 489). Children who gain salaried employment commonly give their first pay cheque to their parents, grandparents and parents' friends, and continue 
redistributing part of all subsequent salaries. Education 'debts' do not map cleanly on to a cost-benefit logic (Bledsoe 1994; Coe 2014). Ideally, children will express unending gratitude for those who financed their schooling, raised and educated them. Successful children 'are not free to enjoy unencumbered the rewards of their success; rather, they should bring benefits to their investors' (Bledsoe 1992: 191).

In 2014, there were six school-age children in the downstairs maisonnée: Khady's two children (a three-year-old boy born in Rhode Island and a fifteenyear-old girl born in Dakar), Khady's deceased sister's two children whose father had also passed away (a boy of nine and a girl of seventeen), and another sister's two children (aged six and eight) whose parents had limited financial means and lived in a house across the street (see Figure 1). Khady's youngest brother also lived downstairs. The maisonnée's investments in this adult brother's private university tuition show how Khady and her sisters prepared the next step of the family cycle of reciprocity by providing an excellent education to the person assumed to be the future head (borom kër) of the downstairs maisonnée.

All school-age children in Khady's maisonnée were enrolled in private and wellreputed French schools (Catholic or secular). They also received Qur'anic and Arabic classes at home every Saturday and homework support almost every weekday evening. Differences in the schools' fees, prestige and distance from the house (which might entail transportation costs) reveal inequalities among children. Analysis of these unequal investments show how maisonnées are constructed through individual relationships of reciprocity that follow the logic of stratified material distribution.

I was surprised to learn that the two children who attended the schools with the best reputations were those who had lost both father and mother. Much of the extensive literature on orphans in West Africa highlights the disadvantages these children face within their host families. But these two children represent a notable exception. They were the children of Khady's eldest sister Mareme. The seventeen-year-old daughter was in her final year at a highly reputed Catholic lycée in downtown Dakar (30,000 CFA francs (FCFA) per month, or roughly $€ 46)$. Her nine-year-old brother attended a Catholic primary school $(18,000$ FCFA/month, €27) closer to home. Khady and her sister who lived in France paid the school fees for Mareme's children.

When their parents died, these children were not fostered to another home but continued living in their maternal grandparents' house. Before her death in 2006, Mareme had worked as an accountant in a state ministry. Her accountancy diploma and steady employment as a civil servant made her a successful eldest child, which she embodied in her familial relations by paying the school fees for some of her younger siblings. Khady explained to me that, in life, Mareme was generous and cared about everyone. Indeed, no praise was too great when Mareme was remembered in her family's house. There was a family narrative of collective success focused on this exemplary image of the generous elder. When she died of cancer at age forty, her younger sisters promised to take good care of her children. They explained that Mareme had wanted her children to be exclusively enrolled in Catholic schools, and they worked to carry out her wish. The orphan children of the sister who was once the entire maisonnée's benefactor thus attended excellent schools. 
Through school payments, adults create strong ties of debt and obligation with children. Financing school fees may mean reimbursing a debt, or creating a new one. Taking care of others' children fulfils the moral obligation to share when you succeed in life. In the case of Mareme's children, Khady and her sister in France made it a point of honour to take care of them. More generally, my interlocutors have always placed particular emphasis on the relationship established with the person who paid for their own education.

The case of the two boys whose parents lived across the street illuminates another facet of intra-family resource allocation: efforts to reduce inequalities and create new indebtedness. Their mother was a housekeeper who had dropped out of school at the elementary level (sister 7 in Figure 1) and their father worked only occasionally. Despite their parents' meagre means, the boys both attended a secular private school nearby $(12,000$ FCFA/month, €18). Khady and another sister who worked at the airport in Dakar (sister 6) paid for their nephews' schooling, helping their struggling sister and ensuring that her children were not forced to attend public school.

When the eldest of the two boys failed a class and was obliged to repeat the year, his aunts were angry. They asked me to advocate on his behalf with the principal of the school, who I knew well, asking him to allow the boy to move up to the next grade. Private schools are costly and parents in Yoff often expressed the idea that there is no point in investing in a child who does not take advantage of the opportunities offered at an expensive school. Collective investments in children who appear less promising were regularly called into question in Khady's downstairs maisonnée. These two boys were inattentive in class and their aunts often said that it was not worth paying for them to attend private school, and yet Khady and her sister continued to cover their school fees. In financing the boys' schooling, Khady and her sister redistributed their resources in a way that served to diminish unevenness between the children in their maisonnée. In so doing, the sisters also accrued new obligations among their nephews, who would hopefully become new benefactors for the maisonnée in the future.

For Khady and her sisters, in paying for all the children's schooling they worked to maintain the upward trajectory of the downstairs maisonnée as a whole. These collective investments in school fees unified the maisonnée, establishing it as a kinship unit in which all the children attended private schools. Khady's sister proudly explained, 'All the children here go to school!', criticizing a neighbour who had sent her son to work with the fishermen nearby when he was only fourteen years old. In this maisonnée, the working adult siblings collectively provided for the private school fees for all the children; the slight differences in the investments they made in each were linked, on the one hand, to the history of resource distribution in the family and, on the other, to the perceived potential of each child.

To evaluate a child's 'potential', adults consider his or her character: 'cleverness' (as reflected in grades) and obedience, which adults often interpreted as an indication of future willingness to demonstrate gratitude. The adults with whom I carried out my fieldwork were also concerned with children's potential vis-àvis migration. At age three, Khady's American-born son was already the recipient of significant educational investments, enrolled in a private Catholic pre-school. Catholic schools are a distinctive choice in Yoff and enrolling a child in a French school at the pre-school level is rare. An American citizen by birth, it 
seemed obvious to family members that Khady's son would return to the US at some point. Later, Khady sent his younger brother, her third child, who was also born in Rhode Island, back to Yoff when he was two years old. The following year, he started attending a new Franco-English 'bilingual' pre-school, near Yoff. Even at their young ages, these children represented future migrants to the US - a destination reputed for its economic opportunities - and were thus treated as future sources of security for the maisonnée.

Diversification of family members' livelihoods and children's future paths is a long-standing strategy African families use to cope with economic risk (Bryceson 2006). Indeed, it is common in West Africa for siblings to benefit from unequal investments as parents try to expand their children's skills, networks and trajectories (Bledsoe 1994). Children who are thought to have high potential as future migrants are often the object of substantial school investments aimed at preparing them for their future abroad.

While Khady and her working sisters provided for all the children's educations, the most promising children benefited from more significant investments. The more successful a child appears to be, the more adults are willing to invest in his or her trajectory. When Mareme's daughter graduated from high school in 2015, everyone in the downstairs maisonnée was concerned about where she would attend university and at what cost. Khady and her sisters had begun preparing for the burden university tuition would add to the maisonnée's school budget. When Mareme's daughter was accepted at a highly selective public university, which was free of charge, included a scholarship for living expenses, and promised a public servant position on graduation, her relatives were all relieved. 'We're saved!' one of Khady's sisters exclaimed with a large smile. As children advance in their studies and tuition fees increase, the maisonnée's school budget is regularly renegotiated. A private university would have been very expensive. The maisonnée was 'saved' both in the present, via tuition savings, and hopefully in the future, since their niece was assured a salaried position.

Finally, investments in education are also related to who family members imagine will take on the role of benefactor and head of the maisonnée. The case of Khady's youngest brother (number 9 in Figure 1) further emphasizes how an individual's claims to funding are linked to gender and anticipated socioeconomic position. This twenty-five-year-old, who attended a Catholic college $(100,000 \mathrm{FCFA} / \mathrm{month}, € 152)$ for a master's degree in management, received assistance from Khady in the US, his sister in France, and a cousin abroad. These three migrant relatives pooled their resources to pay for his schooling, on the assumption that he would bring a wife into their home, inherit a significant portion of the downstairs property, and, if all went as planned, assume the majority of the maisonnée's expenses. Another of Khady's brothers (number 8) was already living downstairs with his wife, but his low-paid job and lack of commitment to the management of family economics made him a less desirable candidate for head of the maisonnée than his younger brother. By funding their youngest brother's advanced studies together, his sisters prepared him to take over the maisonnée's material security.

An examination of investments in education made by members of Khady's maisonnée sheds light on several logics that drive adults' uneven investments in children's education: economic moralities of resource redistribution (repaying and creating new debts, sharing resources and taking up the role of dutiful 
benefactor), parents' status in the family (in terms of gender, generation, education level, income and migration trajectories) and the potential of each child (measured by behaviour, academic success and migration possibilities).

All the children in the downstairs maisonnée benefited from remittances sent by Khady in the US and her sister in France, and those thought to have the highest potential to migrate or redistribute in the future received more. In contrast, Pierrot's sons' future potential did not point as clearly to international migration. Indeed, lacking the proximity to their migrant relatives that their downstairs cousins enjoyed, the school fees of the children in Pierrot's upstairs maisonnée were not assured by benefactors abroad. The next section focuses on how Pierrot Gueye, a non-migrant father, attempted to manage the changing landscape of global and local opportunities with limited material means through a strategic choice of schools for his two school-age sons.

\section{Global inequalities, local investments}

Pierrot was a fifty-year-old father of three who had a degree in law. I had thus understood him to be what Senegalese often call an 'intellectual', a term often used for francophone, formally educated Africans. Pierrot went to university, then worked for several years in an NGO that sent him to various regions in Senegal. Pierrot finally decided to settle down and get married when he was roughly forty years old. He had taken a manual job at a transport company at Dakar airport. His salary was reasonable but did not allow him to save money to build his own house or to support other members of his family. At that point, his prospects for social advancement shrunk: he could no longer afford to travel and he had to support his wife (who did not work) and children. $\mathrm{He}$ often spoke to me about his frustration at being stuck at home without the possibility of migrating. Commenting on the length of time I had studied, he said, 'You're brave, but you're lucky enough to be able to do it because you don't have anyone behind you' - i.e. I had no family to support.

Two of his older brothers had succeeded as civil servants (a high-school teacher and an army officer), built their own houses and left the Gueye home. Pierrot was the last of his mother's children in the paternal house. With a law degree that he did not use and a job that provided few opportunities for advancement, Pierrot had what Bourdieu called an 'interrupted trajectory' (1979: 160-6). His birth family was relatively wealthy, encouraging him to take his time in establishing himself in his career and family. He received a francophone diploma at a time when this level of schooling was perceived to guarantee him a well-paid desk job. This, however, did not prove to be the case because salaried employment became scarce in Dakar by the time he decided to take up responsibilities as a husband and father.

In the Gueye home, Pierrot experienced his declining trajectory relative to the promising paths of his younger half-sisters downstairs. Khady, for example, was less educated than he was but had successfully migrated to the US thanks to her husband. Because Khady's mother had raised him when his own mother was ill, Pierrot was still in debt. Furthermore, because his half-siblings downstairs were his juniors, he was logically positioned to provide material care for them. 
Had he successfully obtained a well-paid position, he could have gone on to provide substantial support for the members of Gueye house more broadly. But over the years, the gap between Pierrot's future prospects and those of his migrant half-sisters had widened. Differences in the siblings' trajectories have been reflected in divergent school strategies for downstairs and upstairs children. Pierrot's choice of schools for his two sons was a careful calculation, shaped by his own limitations in terms of economic means and international connections and each child's unique potential and 'luck'.

Given his own French university education and the fact that all the children downstairs attended French-language schools, Pierrot's choice to send his eldest son to a Franco-Arabic school was unexpected. Indeed, Pierrot's half-sisters have never understood this choice. Pierrot first explained his decision relative to the notion that Arabic and Islamic education are believed to effectively teach obedience and values such as courage, hard work, solidarity with extended kin, and respect for social hierarchies. This form of schooling is also reputed to provide children with God's blessings (baraka) necessary to their success in life (Buggenhagen 2001; Bledsoe and Robey 1986; Bledsoe 1990; 1992). Pierrot explained to me that his son had first gone to the private secular school closest to the house but had done poorly there, having spent most of his time at school playing with his classmates. Pierrot had thus decided to send him out of the neighbourhood to a Franco-Arabic school where he would not know anyone and where he would be disciplined enough to learn well.

Adults often mentioned obedience and willingness to work as key indicators of children's potential. Children should ideally learn to reciprocate the care adults invest in them 'by being obedient and doing household chores quickly and without fuss' (Coe 2012: 916). Later, parents hope that children 'will grow up to both want to and be successful enough to be able to reciprocate in the future' (Coe 2011: 15, italics in the original). Pierrot's choice to enrol his child in a Franco-Arabic school was thus a preventative act, aimed at cultivating obedience that could later shape him into a willing benefactor.

Surprisingly, the Franco-Arabic school his son attended was more expensive $(15,000 \mathrm{FCFA} / \mathrm{month}, € 23)$ than one of the schools the children downstairs attended. Pierrot justified this difference in price saying that while the FrancoArabic school might appear more expensive, 'everything was included' at his son's school. He continued, saying that he actually saved money by avoiding the expense of a separate Arabic tutor (7,500 FCFA/month/child, €11) and homework support four evenings a week $(2,000 \mathrm{FCFA} / \mathrm{month} / \mathrm{child}, € 3)$ that the downstairs children received. In this way, Pierrot explained the Franco-Arabic school as a rational economic choice, since overall it cost less than the secular French school plus Arabic education in which the downstairs maisonnée invested.

Pierrot further explained to me that 'at a certain age it is necessary to show one's loyalty to the religion'. He continued, saying that he generally wore traditional clothes or djellaba and went to the mosque each Friday, a mark of his own religious devotion. By choosing a Franco-Arabic school, Pierrot invested in a local form of distinction for himself and his maisonnée, an alternative value system focused on religious respectability (Rodriguez 2015). His choice reflected his investment in a Senegalese and Muslim identity rather than in an international and Western one, in contrast to his half-sisters downstairs whose children attended French and Franco-English schools. 
Several informants described choosing a school for a child as something akin to placing a bet on the child's 'luck' (wërsëg). In Wolof, luck is a term that combines the concept of divine destiny with the idea that one must work to find one's fate (see also Gaibazzi 2015; Elliot 2016). To face uncertainty, people must 'expos[e] themselves to the possibility of getting a chance' (Di Nunzio 2015: 153). 'How can we guess where a child's luck will lie?' Pierrot asked as we discussed his schooling choices. He emphasized the possibility that the knowledge of Islam and the Arabic language could present opportunities for his son, potentially providing access to other life options through the economic networks of Islamic brotherhoods (local or transnational) (see Diouf 2000) or through migration to Arab or Islamic countries for school ${ }^{11}$ or work.

Pierrot's own interrupted trajectory was linked to Senegal's experience of what Jennifer Cole has called the 'disintegration of the modern dream of education' (2011: 69), which took place as French education could no longer guarantee the economic security of African urban families (see also Gérard 1999; Antoine et al. 2001; Comaroff and Comaroff 2004: 339-44). In Senegal, some middleclass parents have begun to invest in Franco-Arabic education (Lewandowski 2011; Dia 2015). With fewer means than migrants and with better prospects in local value systems, educated parents such as Pierrot may find Franco-Arabic education particularly appropriate for certain children. In a changing Senegalese society, with access to national diplomas, Arabic speakers may well occupy enviable positions in the future.

During my fieldwork in 2015, Pierrot was choosing which school his second son would attend. He described himself as pondering, groping in the dark, comparing options, while trying to keep afloat financially. In the end, Pierrot chose to send his second son to a secular French school that cost 9,000 FCFA per month (approximately €14). Laughing, Pierrot explained that his younger son was too insolent to go to the Franco-Arabic school like his eldest, adding with a delighted smile, 'He asks too many questions!' One of his half-sisters explained to me that Pierrot's second son was very clever ('dafa muus torob'). French schools still provide privileged access to the contractual job market in Senegal and to migration opportunities as a student. As a result, Pierrot strategically offered a French education to his second son, who showed particular promise.

Pierrot has worked hard to transmit his social position to his children. Bourdieu suggests that people who have experienced a declining social trajectory ('les déclassés') are identified by the significant efforts they invest in the maintenance of their current existence (1979: 122). Pierrot's efforts to offer his children an advantageous future lie at the intersection of diversifying their trajectories and gambling on Arabic-language and religious legitimacy. Worries about the future can be even more intense for non-migrant parents than they are for those with close connections to relatives abroad, concerns that are reflected in Pierrot's many hesitations regarding schooling choices and his diverse strategies for his children's destinies.

\footnotetext{
${ }^{11}$ Mainly in Egypt, Morocco, Tunisia, Libya, Lebanon, Saudi Arabia, Kuwait, Iraq and Iran (Dia 2015).
} 


\section{Conclusion}

During the colonial and post-independence periods in Senegal, francophone education indexed social achievement for urban families. Today, the privatization of Dakar's educational landscape has rendered school choices more complicated, contingent on the livelihoods and migration possibilities adults envisage for each child. In neoliberal capitalism, private schooling has appeared as an element of middle-class consumption and a new field of social struggle and distinction in urban Senegal. The myriad different schools available each give access to different socio-economic trajectories. Simultaneously, Muslim parents juggle multiple social norms, between local and global identities, in their efforts to make ends meet and maintain their claims to middle-class membership.

Through this analysis of school choices in one family house in Dakar's lower middle class, I have shown how hopes for the future can be materialized in children's education. This snapshot of the expectations associated with school choices provides an insight into how maisonnées in Dakar deal with the daily concern of reproducing their social position. How can one know which child will be successful? Each maisonnée struggles to choose appropriate schools for children according to their 'potential' (character, skills, probability of migration) and depending on their parents' status in the kinship group.

In transnational Dakar, the neoliberal diversification of private schools meets the logic of unequal redistribution of resources within families. Socio-economic inequalities between adult siblings are both reproduced and rectified in school choices for their children. School investments are carefully organized in an effort to secure the maisonnée's future needs and hopefully achieve social mobility. Global inequalities between daily kinship groups such as Khady's and Pierrot's maisonnées are evident in the ways in which they cope with the unevenness of the private school landscape as a result of their available financial means and future opportunities.

Successful migrants can perform their role of family benefactor in providing schooling payments for several children. In so doing, they take their turn in intergenerational cycles of reciprocity at a distance. In a global world, migrants from low-income countries are often employed on the bottom rungs of Western job markets, as was the case for Khady Gueye (a nurse's assistant). As such, in these strategic education choices, migrants also ensure their own security for the future, when they return to Senegal in retirement, hopefully rich owners of multiple houses but possibly poorer than hoped, old and in need of care. In countries such as Senegal, where the state provides citizens little assistance, uncertainty is characteristic of the neoliberal economy, even for maisonnées that include migrants.

For non-migrant parents, cultivating a promising future for one's children locally (with the ever-present hope of opportunities abroad) represents a tricky challenge. With Dakar's diverse schooling options, Pierrot navigated paths unexplored by his migrant sisters. He struggled to reposition himself positively and establish a favourable position for his children in a local, religiously oriented value system (Narotzky and Besnier 2014). In times of neoliberal uncertainty, building a beneficial future for one's children requires broadening the territories and horizons of their opportunities as much as possible. 


\section{Acknowledgements}

I am deeply grateful to the members of Senegalese maisonnées who warmly welcomed me into their homes in Senegal, Italy and the US. I sincerely thank Chelsie Yount-André, Aïssatou Mbodj-Pouye, Elodie Druez, Ismaël Moya, Hannah Hoechner and Florence Weber for their many helpful comments on this article. I am grateful for their relevant remarks and suggestions to the discussants on the presentations of this paper: Niko Besnier at the 'Social mobility, spatial mobility' workshop organized at École Normale Supérieure de Paris in October 2016, and Jennifer Cole at the 2016 American Anthropological Association annual meeting. I sincerely thank the organizers of the 'New social dynamics in Senegal' workshop that took place at Université Libre de Bruxelles in March 2017, where this article was also discussed. The transnational fieldwork on which this article is based was funded by the French Institute for Demographic Studies (INED) and the Transfers Labex (École Normale Supérieure).

\section{References}

Adepoju, A. (2000) 'Issues and recent trends in international migration in subSaharan Africa', International Social Science Journal 52: 383-94.

Adjamagbo, A., F. B. Dial and P. Antoine (2004) Le dilemme des Dakaroises: entre travailler et 'bien travailler'. DIAL documents de travail DT/2003/08. Paris: Développement, Institutions et Mondialisation (DIAL).

Antoine, P., M. Razafindrakoto and F. Roubaud (2001) 'Contraints de rester jeunes? Évolution de l'insertion dans trois capitales africaines: Dakar, Yaoundé, Antananarivo', Autrepart 18 (2): 17-36.

Baldassar, L. and L. Merla (2013) Transnational Families, Migration and the Circulation of Care: understanding mobility and absence in family life. New York NY: Routledge.

Bledsoe, C. (1990) "No success without struggle": social mobility and hardship for foster children in Sierra Leone', Man 25 (1): 70-88.

Bledsoe, C. (1992) 'The cultural transformation of Western education in Sierra Leone', Africa 62 (2): 182-202.

Bledsoe, C. (1994) 'Children are like young bamboo trees: potentiality and reproduction in sub-Saharan Africa' in K. Lindahl-Kiessling and H. Landberg (eds), Population, Economic Development, and the Environment. Oxford and New York NY: Oxford University Press.

Bledsoe, C. (1995) 'Marginal members: children of previous unions in Mende households in Sierra Leone' in S. Greenhalgh (ed.), Situating Fertility: anthropology and demographic inquiry. Cambridge: Cambridge University Press.

Bledsoe, C. and K. Robey (1986) 'Arabic literacy and secrecy among the Mende of Sierra Leone', Man 21 (2): 202-26.

Bledsoe, C. H. and P. Sow (2011) 'Back to Africa: second chances for the children of West African immigrants', Journal of Marriage and Family 73: 747-62.

Bourdieu, P. (1972) Esquisse d'une Théorie de la Pratique: précédé de 'Trois Etudes d'Ethnologie Kabyle'. Geneva: Librairie Droz.

Bourdieu, P. (1979) La Distinction: critique sociale du jugement. Paris: Éditions de Minuit. 
Bryceson, D. (2006) 'African urban economies: searching for sources of sustainability' in D. F. Bryceson and D. Potts (eds), African Urban Economies. London: Palgrave Macmillan.

Bryceson, D. and U. Vuorela (2002) The Transnational Family: new European frontiers and global networks. Oxford: Berg Publishers.

Buggenhagen, B. A. (2001) 'Prophets and profits: gendered and generational visions of wealth and value in Senegalese Murid households', Journal of Religion in Africa 31: 373-401.

Buggenhagen, B. A. (2012) Muslim Families in Global Senegal: money takes care of shame. Bloomington IN: Indiana University Press.

Charlier, J.-E. (2004) 'Les écoles au Sénégal: de l'enseignement officiel au daara, les modèles et leurs répliques', Cahiers de la Recherche sur l'Éducation et les Savoirs 3: 35-53.

Coe, C. (2011) 'What is love? The materiality of care in Ghanaian transnational families', International Migration 49 (6): 7-24.

Coe, C. (2012) 'Growing up and going abroad: how Ghanaian children imagine transnational migration', Journal of Ethnic and Migration Studies 38 (6): 913-31.

Coe, C. (2014) The Scattered Family: parenting, African migrants, and global inequality. Chicago IL: University of Chicago Press.

Cole, J. (2010) Sex and Salvation: imagining the future in Madagascar. Chicago IL: University of Chicago Press.

Cole, J. (2011) 'A cultural dialectics of generational change: the view from contemporary Africa', Review of Research in Education 35 (1): 60-88.

Cole, J. (2014) 'Producing value among Malagasy marriage migrants in France: managing horizons of expectation', Current Anthropology 55 (S9): S85-S94.

Cole, J. and C. Groes (2016) 'Introduction: affective circuits and social regeneration in African migration' in J. Cole and C. Groes (eds), Affective Circuits: African migration to Europe and the pursuit of social regeneration. Chicago IL: University of Chicago Press.

Comaroff, J. and J. L. Comaroff (2004) 'Afromodernity and the new world order' in B. Weiss (ed.), Producing African Futures: ritual and reproduction in a neoliberal age. Leiden: Brill.

D'Aoust, S. (2013) 'Écoles franco-arabes publiques et daaras modernes au Sénégal: hybridation des ordres normatifs concernant l'éducation', Cahiers de la Recherche sur l'Éducation et les Savoirs 12: 313-38.

Darbon, D. (2012) 'Classe(s) moyenne(s): une revue de la littérature', Afrique Contemporaine 4: 33-51.

Dia, H. (2015) 'Les diplômés en langue arabe au sein de l'élite sénégalaise: du symbolique à l'académique', Cahiers de la Recherche sur l'Éducation et les Savoirs 14: 187-206.

Dia, H., C. Hugon and R. d'Aiglepierre (2016) 'Le monde des écoles coraniques: essai de typologie pour le Sénégal', Afrique Contemporaine 257 (1): 106-10.

Di Nunzio, M. (2015) 'Embracing uncertainty: young people on the move in Addis Ababa's inner city' in E. Cooper and D. Pratten (eds), Ethnographies of Uncertainty in Africa. Basingstoke: Palgrave Macmillan.

Diouf, M. (2000) 'The Senegalese Murid trade diaspora and the making of a vernacular cosmopolitanism', Public Culture 12 (3): 679-702.

Elliot, A. (2016) 'The makeup of destiny: predestination and the labor of hope in a Moroccan emigrant town', American Ethnologist 43 (3): 488-99. 
Fall, P. D. (2016) Des Francenabe aux Modou-Modou: l'émigration sénégalaise contemporaine. Paris: L'Harmattan.

Gaibazzi, P. (2015) 'The quest for luck: fate, fortune, work and the unexpected among Gambian Soninke hustlers', Critical African Studies 7 (3): 227-42.

Gérard, É. (1999) 'Logiques sociales et enjeux de scolarisation en Afrique: réflexions sur des cas d'écoles maliens et burkinabè', Politique Africaine 76 (4): $153-63$.

Gollac, S. (2003) 'Maisonnée et cause commune: une prise en charge familiale' in F. Weber, S. Gojard and A. Gramain (eds), Charges de Famille: dépendance et parenté dans la France contemporaine. Paris: La Découverte.

Grysole, A. and C. Beauchemin (2013) 'Les allers-retours des enfants de l'immigration sub-saharienne: "Les filles ou les garçons d'abord"?', Migrations Société 147-8: $127-42$.

Guyer, J. I. (1981) 'Household and community in African studies', African Studies Review 24 (2-3): 87-138.

Guyer, J. I. and P. Peters (1987) 'Conceptualizing the household', Development and Change 18: 197-213.

Hoechner, H. (forthcoming) 'Islamic schooling, return and the second generation' in R. Cohen and C. Fischer (eds), Routledge Handbook of Diaspora Studies. London: Routledge.

Hunter, M. (2014) 'The bond of education: gender, the value of children, and the making of Umlazi township in 1960s South Africa', Journal of African History 55 (3): 467-90.

Kane, O. (2011) The Homeland Is the Arena: religion, transnationalism, and the integration of Senegalese immigrants in America. New York NY: Oxford University Press.

Kea, P. (2016) 'Photography and technologies of care: migrants in Britain and their children in the Gambia' in J. Cole and C. Groes (eds), Affective Circuits: African migration to Europe and the pursuit of social regeneration. Chicago IL: University of Chicago Press.

Lessault, D. and M.-L. Flahaux (2013) 'Regards statistiques sur l'histoire de l'émigration internationale au Sénégal', Revue Européenne des Migrations Internationales 29 (4): 59-88.

Lewandowski, S. (2011) 'Politiques de lutte contre la pauvreté et inégalités scolaires à Dakar: vers un éclatement des normes éducatives?', Autrepart 3: 37-56.

Lewandowski, S. and B. Niane (2013) 'Acteurs transnationaux dans les politiques publiques d'éducation: exemple de l'enseignement arabo-islamique au Sénégal' in M.-C. Diop (ed.), Sénégal (2000-2012): les institutions et politiques publiques à l'épreuve d'une gouvernance libérale. Paris: Karthala.

Maurer, B. (2009) 'Moral economies, economic moralities' in K. E. Browne and B. L. Milgram (eds), Economics and Morality: anthropological approaches. New York NY: Altamira.

Motta, E. (2014) 'Houses and economy in the favela', Vibrant: Virtual Brazilian Anthropology 11 (1): 118-58.

Moya, I. (2017) De l'Argent aux Valeurs: femmes, économie, et société à Dakar. Paris: Société d'Ethnologie.

Narotzky, S. and N. Besnier (2014) 'Crisis, value, and hope: rethinking the economy: an introduction to supplement 9', Current Anthropology 55 (S9): S4-S16. 
Niang, F. (2014) 'L'école primaire au Sénégal: éducation pour tous, qualité pour certains', Cahiers de la Recherche sur l'Éducation et les Savoirs 13: 239-61.

Noret, J. (2016) 'Social (im)mobilities in Africa: an introduction'. Paper presented at 'Social (im)mobilities in Africa: ethnographic approaches', Institut de Sociologie, Université Libre de Bruxelles, 9-10 February.

Osmont, A. (1995) La Banque Mondiale et les Villes du Développement à l'Ajustement. Paris: Karthala.

Razy, E. and V. Baby-Collin (2011) 'La famille transnationale dans tous ses états', Autrepart 57-8: 7-22.

République du Sénégal (2013) Rapport National sur la Situation de l'Éducation. Dakar: Ministère de 1'Éducation Nationale.

République du Sénégal (2015) 'Situation économique et sociale régionale'. Dakar: Service Régional de la Statistique et de la Démographie de Dakar, Ministère de l'Économie, des Finances et du Plan.

Riddell, J. (1992) 'Things fall apart again: structural adjustment programmes in sub-Saharan Africa', Journal of Modern African Studies 30 (1): 53-68.

Rodriguez, A. L. (2015) 'Three stories about living without migration in Dakar: coming to terms with the contradictions of the moral economy', Africa 85 (2): 333-55.

Thelen, T., C. Coe and E. Alber (2013) The Anthropology of Sibling Relations: shared parentage, experience, and exchange. New York NY: Palgrave Macmillan.

Villalón, L. A. and M. Bodian (2012) 'Religion, demande sociale, et réformes éducatives au Sénégal'. Research Report 05. London: Africa Power and Politics Programme.

Ware, R. T. (2009) 'The longue durée of Quran schooling, society, and state in Senegambia' in M. Diouf and M. Leichtman (eds), New Perspectives on Islam in Senegal. New York NY: Palgrave Macmillan.

Weber, F. (2002) 'Pour penser la parenté contemporaine' in D. Debordeaux and P. Strobel (eds), Les solidarités familiales en question: entraide et transmission. Collection Droit et Société. Paris: LGDJ.

Weber, F. (2005) Le Sang, le Nom, le Quotidien: une sociologie de la parenté pratique. Paris: Aux Lieux d'Être.

Yount-André, C. (2017) 'Indexing integration: hierarchies of belonging in secular Paris', Journal of the Anthropological Society of Oxford 9 (1): 43-64.

\begin{abstract}
As in many parts of the world, the school system in Senegal has suffered from state budget cuts associated with structural adjustment and neoliberal reform in the 1980 s. As a result, the quality of elementary public schools has been compromised; meanwhile a significant private sector developed. This article analyses the proliferation of private schools in Dakar and the ways in which Senegalese parents navigate the multiplicity of school types (French, Franco-Arabic or Franco-English, Catholic or secular), to understand how families struggle to ensure their social and material reproduction in a neoliberal economy. I suggest that educational investments are situated at the intersection of global and intra-family inequalities. International migration has made global inequalities apparent within and between Senegalese families, who are unequally positioned depending on whether they include members living abroad.
\end{abstract}




\section{Résumé}

Comme dans d'autres régions du monde, le système scolaire sénégalais a souffert des coupes budgétaires de l'État liées aux ajustements structurels et aux réformes néolibérales des années 1980 . Une des conséquences a été la diminution de la qualité des écoles élémentaires publiques, qui a engendré un développement important du secteur privé. Cet article analyse la prolifération des écoles privées à Dakar et la manière dont les parents sénégalais réagissent face à cette multiplicité des types d'écoles (français, franco-arabe ou franco-anglais, catholique ou laïque), pour comprendre comment les familles luttent pour assurer leur reproduction sociale et matérielle dans une économie néolibérale. Je suggère que les investissements éducatifs se situent à l'intersection des inégalités globales et intrafamiliales. Les migrations internationales rendent d'autant plus visibles les inégalités globales entre et au sein des familles sénégalaises. Disposer ou non de membres vivant à l'étranger positionne inégalement les familles dakaroises dans les hiérarchies socio-économiques. 